\title{
Deviant Workplace Behavior Causative Factors (The Effect of Interpersonal Justice and Non-Physical Work Environment on Workplace Deviance with Job Satisfaction as a Mediation variable in Universitas Negeri Padang Employees)
}

\author{
Ega Frima Anjani', Syahrizal ${ }^{2 *}$ \\ 1Universitas Negeri Padang, Padang, Indonesia, \egafanjani@gmail.com \\ 2Universitas Negeri Padang, Padang, Indonesia, \syahrizal@fe.unp.ac.id \\ *Corresponding Author
}

\begin{abstract}
This study aims to analyze the effect of interpersonal justice and non-physical work environment on deviant workplace behavior with job satisfaction as a mediating variable in Universitas Negeri Padang Employees. The population of this study were all employees of Universitas Negeri Padang who were civil servants with a total sample of 195 respondents. The analysis technique used is SEM-PLS. The results of the study show that interpersonal justice and non-physical environment have a positive and significant effect on job satisfaction. Then, job satisfaction has a significant negative effect on deviant workplace behavior, and interpersonal justice has a significant negative effect on deviant workplace behavior, but the non-physical work environment has a negative and insignificant effect on deviant workplace behavior. Furthermore, job satisfaction is a mediator of interpersonal justice towards deviant workplace behavior, but to test the effect of mediating variables on job satisfaction in a non-physical work environment on deviant workplace behavior cannot be continued because, a direct relationship between exogent variables (non-physical work environment) to the endogent variable (deviant workplace behavior) is not significant.
\end{abstract}

Keywords: interpersonal justice, non-physical work environment, job satisfaction, and deviant workplace behavior

\section{Introduction}

Companies or organizations usually have problems when employees at the company make irregularities. Basically the organization has a binding work rules system. Any deviations made by employees will have deviant consequences and behavior by employees in the workplace which will certainly have a negative efffect on the organization. (Griffin \& Lopez, 2005) said that irregularities in the workplace are behaviors that deviate from the norms and significant rules of the organization, while threatening social welfare. Another understanding of the behavior of irregularities in the workplace according to (Robinson et al., 2008) is the action of employees who intentionally result in negative consequences. Basically, the behavior shown by someone who is deemed deviant when violating habits and policies or regulations that exist within an organization can endanger the organization itself and the people who are in it. Deviation in the workplace is a behavior that can violate organizational norms, oppose the organization and will later harm the organization, others, or harm themselves. Therefore, deviant workplace behavior must be controlled.

The study was conducted at Universitas Negeri Paadang, which is one of the state universities in the city of Padang, West Sumatra UNP aims to realize excellence in the field of education through efforts to develop academic and / or professional education. Therefore, to realize these advantages certainly the role of employees is very important. Problems and obstacles that arise and will cause losses must be addressed immediately so that the goal is achieved. To identify the initial problem, the researcher observed and interviewed several Padang State University employees about what deviant workplace behavior had been done. Some of them, (1) delegate responsibility to others, (2) are not in the office during working hours, (3) behave rudely, (4) use office facilities for personal needs, and (5) take longer breaks . 
Deviant workplace behavior can occur from the individual's own internal and because of the interpersonal injustices that are felt. Interpersonal justice relates directly to individuals. Not being treated with courtesy and respect will encourage employees to do deviations because they feel unappreciated. Getting inappropriate remarks and comments by superiors also encourages employees to commit deviant workplace behavior.

(Judge, Scott, \& Ilies, 2006) argue that the more days, interpersonal / individual meetings often occur within organizations, so interpersonal justice becomes more psychologically meaningful for employees. So from that interpersonal justice has the strongest relationship in terms of behavioral deviations in employees. If the employee does not obtain justice, the greater the chance of deviant behavior in the organization.

The non-physical work environment can also be a factor for the employee to make deviant workplace behavior. Non-physical work environment includes relationships between superiors and subordinates as well as relationships with colleagues. If the relationship does not go well, the higher the behavior of deviations in the workplace carried out by employees. For example, the way employers and colleagues communicate things, if communication is not done properly, then irregularities in the workplace can occur.

Job satisfaction can also give effect the occurrence of deviant behavior in the workplace carried out by individuals / employees. Employees do not feel satisfied with the ability to carry out their duties, the tasks given are not according to skills, uncooperative co-workers will be able to influence employees to make irregularities at work. The effect of interpersonal justice on deviations is mediated through job satisfaction. If individuals get high interpersonal justice, they get job satisfaction and low deviation behavior, whereas if individuals experience dissatisfaction, then deviant workplace behavior so high.

\section{Methods}

This study aims of the effect of interpersonal justice and non-physical work environment on deviant workplace behavior with job satisfaction as a mediating variable in Universitas Negeri Padang employees. The population in this study were all UNP employees with civil servant status as many as 383 employees, with a sample of 195 respondents selected based on purposive sampling technique. The data analysis technique used is SEM-PLS. Time of research in March 2019.

\section{Results and Discussion \\ Outer Model Testing \\ Loading Factor}

Figure 1 shows the results of the structural model in this study which consists of two exigent variables, one endogent variable and one mediating variable, and the value of outer loading on each of these variables. On the variable Interpersonal Justice (X1) consists of 4 (four) indicators and 4 statements, Non-Physical Work Environment (X2) consists of 3 (three) indicators and 9 statements, Job Satisfaction (M) consists of 5 (five) indicators and 11 statement, Deviant Workplace Behavior (Y) consists of 4 (four) indicators and 7 statements. 


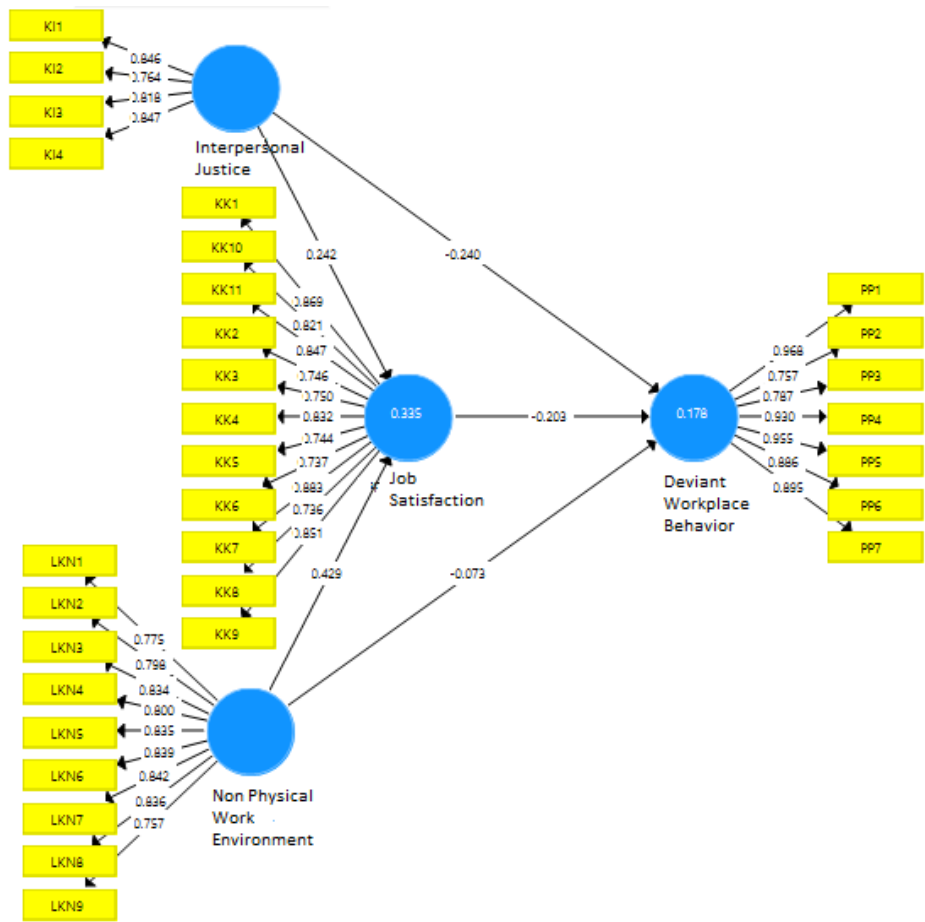

Figure 1 Results of the PLS Algorithm

Source: Results of Primary Data Processing (2019)

\section{Average Variance Extracted (AVE)}

This test aims to measure the level of variance in a construct component collected from the indicator. The reconditioned AVE value must be more than 0.5. The AVE value of each latent variable is as follows:

Table 1 Average Variance Extracted (AVE)

\begin{tabular}{lc}
\hline \multicolumn{1}{c}{ Variabel } & Average Variance Extracted (AVE) \\
\hline Interpersonal Justice $(\mathrm{X} 1)$ & 0,671 \\
\hline Non-Physical Work Environment $(\mathrm{X} 2)$ & 0,662 \\
\hline Job Satisfaction $(\mathrm{M})$ & 0,646 \\
\hline Deviant Workplace Behavior $(\mathrm{Y})$ & 0,784 \\
\hline
\end{tabular}

Source: Results of Primary Data Processing (2019)

In the table above it can be concluded that the variables in this study have met the convergent validity test criteria.

\section{Composite reliability}

The following are the cronbach's alpha values and the composite reliability values of each variable:

Table 2 Cronbach's Alpha dan Composite Reliability

\begin{tabular}{lcc}
\hline \multicolumn{1}{c}{ Variabel } & Cronbach's Alpha & Composite Reliability \\
\hline Interpersonal Justice $(\mathrm{X} 1)$ & 0,837 & 0,891 \\
\hline $\begin{array}{l}\text { Non-Physical Work Environment } \\
(\mathrm{X} 2)\end{array}$ & 0,936 & 0,946 \\
\hline Job Satisfaction $(\mathrm{M})$ & 0,945 & 0,952 \\
\hline Deviant Workplace Behavior $(\mathrm{Y})$ & 0,953 & 0,962 \\
\hline
\end{tabular}

Source: Results of Primary Data Processing (2019) 
Composite reliability is a stage used to test the reliability of indicators for a variable. An indicator reliable requirements if it has a reliability composite value $>0.6$. Reliability with composite reliability methods can also be strengthened by using the value of Cronbach's Alpha. A variable is when Cronbach's Alpha value $>0.7$. In the table above shows each research variable has met the assessment criteria so that it can be concluded that the overall variable is said to be reliable.

\section{Inner Model Testing \\ R-Square $\left(\mathbf{R}^{2}\right)$}

Analysis of variant $\left(\mathrm{R}^{2}\right)$ or Determination Test is to find out the influence of the exogent variable on the endogent variable, the value of the coefficient of determination can be shown in the following table:

Table 3 R-Square

\begin{tabular}{lc}
\hline \multicolumn{1}{c}{ Variabel } & R Square \\
\hline Deviant Workplace Behavior $(\mathrm{Y})$ & 0,178 \\
\hline Job Satisfaction $(\mathrm{M})$ & 0,335 \\
\hline Source: Results of Primary Data Processing (2019)
\end{tabular}

In the table, can be seen $\mathrm{R}^{2}$ in the deviant workplace behavior is 0.178 or $17.8 \%$ which is the effect of interpersonal justice, non-physical work environment, and job satisfaction, and the rest effect by other variable is $82.2 \%$. $\mathrm{R}^{2}$ job satisfaction variable is 0.335 or $33.5 \%$ which is the effect of interpersonal justice and non-physical work environment, then the rest effect by other variable is $66.5 \%$.

\section{Hypothesis Testing}

Table 4 Hypothesis Testing

\begin{tabular}{clccc}
\hline Hypothesis & \multicolumn{1}{c}{ Effect } & Coefficient Path & t-statistic & Explanation \\
\hline H1 & IJ -> JS & 0,242 & 3,371 & Supported \\
\hline H2 & NPW -> JS & 0,429 & 6,422 & Supported \\
\hline H3 & JS -> DWB & $-0,203$ & 2,945 & Supported \\
\hline H4 & IJ -> DWB & $-0,240$ & 2,938 & Supported \\
\hline H5 & NPW-> DWB & $-0,073$ & 0,747 & Unsupported \\
\hline H6 & IJ -> JS -> DWB & $-0,049$ & 2,113 & Supported \\
\hline H7 & NPW -> JS -> & $-0,087$ & 2,322 & Unsupported \\
& DWB & & & \\
\hline
\end{tabular}

\section{Direct Effect}

Hypothesis 1

Interpersonal justice (X1) has an effect on job satisfaction (M). The effect of interpersonal justice on job satisfaction gives a t-statistic of 3.371> 1.96. These results conclude that interpersonal justice has a significant effect on job satisfaction on UNP employees. The effect of interpersonal justice on job satisfaction is positively indicated by the path coefficient of 0.242 . This shows that the more interpersonal justice obtained, the significantly higher job satisfaction. H1 is supported.

Hypothesis 2

Non-physical work environment (X2) has an effect on job satisfaction (M). The effect of the nonphysical work environment on job satisfaction gives a t-statistic of $6.422>1.96$. These results conclude that the non-physical work environment has a significant effect on job satisfaction on UNP employees. The influence of the non-physical work environment on job satisfaction is positively indicated by the path coefficient of 0.429. This shows that the better the non-physical work environment is obtained, the significantly higher job satisfaction. $\mathrm{H} 2$ is supported. 


\section{Hypothesis 3}

Job Satisfaction $(\mathrm{M})$ affects the deviant workplace behavior $(\mathrm{Y})$. The effect of job satisfaction on deviant workplace behavior gives a t-statistic of 2.945> 1.96. These results conclude that job satisfaction has a significant effect on the deviant workplace behavior for UNP employees. The effect of job satisfaction on deviant workplace behavior is negative as indicated by the path coefficient of 0.203 . This shows that the higher job satisfaction is obtained, the less deviant workplace behavior. $\mathrm{H} 3$ is supported.

\section{Hypothesis 4}

Interpersonal justice (X1) affects on deviant workplace behavior (Y). The effect of interpersonal weakness on deviant workplace behavior gives a t-statistic of 2.938> 1.96. These results conclude that interpersonal justice has a significant effect on deviant workplace behavior for UNP employees. The effect of interpersonal justice on the behavior of deviant workplace behavior is negative indicated by the path coefficient of -0.240 . This shows that the higher the interpersonal justice gained, the less deviant workplace behavior. H4 is supported.

\section{Hypothesis 5}

Non-physical work environment (X2) affects on deviant workplace behavior (Y). The influence of non-physical work environment on deviant workplace behavior results in t-statistics of $0.747<1.96$. These results conclude that the non-physical work environment does not significantly on deviant workplace behavior for UNP employees. The effect of interpersonal justice on deviant behavior in the workplace is indicated by the path coefficient of -0.073 . This means that the better or not the nonphysical work environment obtained, does not affect deviant workplace behavior. Therefore H5 is unupported.

\section{Indirect Effect}

Hypothesis 6

Job satisfaction (M) mediates the effect of interpersonal justice (X1) on deviant workplace behavior $(Y)$. The indirect effect of job satisfaction as a mediator between the effect of interpersonal justice on deviant workplace behavior is $2.113>1.96$. It can be concluded that job satisfaction mediates the effect of interpersonal justice on deviant workplace behavior in UNP employees significantly. It means that the more interpersonal justice that is felt, it will increase employee job satisfaction, and then the deviant workplace behavior will decrease or decrease significantly. H6 is supported.

\section{Hypothesis 7}

Job satisfaction (M) mediates the effect of non-physical work environment (X2) on deviant workplace behavior (Y). From the results of testing on the structural model (inner model) it is known that the effect of the non-physical work environment on deviant workplace behavior is not significant with t-statistics of $0.747<1.96$, then the effect of the non-physical work environment on job satisfaction is significant with t-statistics 6.422> 1.96, and the effect of job satisfaction on deviant workplace behavior significant with t-statistics 2.945> 1.96. In accordance with the rules of Baron and Kenney in (Jogiyanto, 2011) that testing of mediation effects can be done if the main effect (direct relationship of the independent variable to the dependent) is significant. If this does not significant, the mediation effect test cannot continue. The exogent variable in this study (non-physical work environment) has a negative but not significant effect on the endogent variable (behavior deviation in the workplace). Therefore H7 is unsupported. 


\section{Discussion}

The Effect of Interpersonal Justice on Job Satisfaction

Interpersonal justice has a positive and significant effect on job satisfaction in UNP employees. The greater the interpersonal justice that is felt, the higher the job satisfaction gained by employees. Organizations and companies must pay attention to interpersonal justice in order to create job satisfaction that will be felt by employees. In accordance with the theory of justice where employees will compare the justice they get. If low, job satisfaction decreases, productivity decreases.

The findings of this study prove that interpersonal justice is a factor that can affect job satisfaction because justice obtained by employees individually or interpersonally will increase job satisfaction of the employee. This is also supported by the results of the study (Judge et al., 2006) said interpersonal justice has a positive effect on job satisfaction. If employees obtain interpersonal justice, their job satisfaction will increase. And if employees don't get interpersonal justice, the job satisfaction they feel is definitely decreasing.

The Effect of Non-Physical Work Environment on Job Satisfaction

The non-physical work environment has a positive and significant effect on job satisfaction of UNP employees. It means that the better the non-physical work environment that is felt by employees, such as relations with superiors, fellow colleagues, and communication between individuals / employees, the increasing job satisfaction of UNP employees. The good or bad relationship between individuals in an organization will certainly have an influence on the individual's feelings. In this study the highest average score on each item was almost the same, meaning that employees had felt that the non-physical work environment they had was good, so they felt their job satisfaction had increased. The results of the study are supported by the results of the study (Kafui Agbozo, 2017), the non-physical work environment has an effect on job satisfaction. If it has a positive effect, employees get satisfaction from doing the work, while a negative work environment will make employees feel dissatisfied.

\section{The Effect of Job Satisfaction on Deviant Workplace Behavior}

Job satisfaction has a negative and significant effect on deviant workplace behavior for UNP employees. If employees get job satisfaction, then the deviant workplace behavior will decrease. Job satisfaction is very important for every employee because without job satisfaction, the employee will not work well to achieve organizational goals. Satisfied or dissatisfied employees must have an influence on behavior in individuals at work.

According to (Omar, Halim, Zamani, Farhadi, Nasir, \& Khairudin, 2011) job satisfaction negatively affects on deviant workplace behavior. If employees experience job satisfaction, then deviant workplace behavior will not occur. A very important work attitude is job satisfaction which refers to pleasant or positive emotions that result from the assessment of work. If job satisfaction, emotions are received positively, then behavior will not occur does not occur.

The Effect of Interpersonal Justice on Deviant Workplace Behavior

Interpersonal justice has a negative and significant effect on deviant workplace behavior for UNP employees. The more interpersonal justice felt by employees so deviant workplace behavior will diminish. Because interpersonal justice is directly related to each individual, if the employee does not obtain justice, the opportunity for the occurrence of deviant behavior in the organization is greater. Research conducted by (Berry, Ones, \& Sackett, 2007) also states that interpersonal injustice affects the deviations in the workplace. So from that interpersonal justice felt by employees has an influence and will lead to their behavior.

The Effect of Non-Physical Work Environment on Deviant Workplace Behavior

Non-physical work environment does not significantly effect on deviant workplace behavior. It means that whether or not the non-physical work environment perceived by employees will not affect 
the behavior deviant workplace behavior. The results of this study contradict with (Henle, 2005), that deviant behavior can be influenced by the work environment in the organization not only the personality or individual characteristics of the employee. The results of the study (Cahyani, 2016), the work environment or unpleasant working atmosphere proved to influence the deviant behavior because when there was a dispute between employees in the workplace there would be no good cooperation and impact on deviating employees at work

Job Satisfaction Mediates Interpersonal Justice to Deviant Workplace Behavior

The research results show that job satisfaction mediates the effect of interpersonal justice on deviant workplace behavior. When the interpersonal justice felt higher, job satisfaction of employees higher, and then the deviant workplace behavior in UNP employees will decrease. To see the role of the mediating variable job satisfaction, it can be seen from the direct and indirect influence of interpersonal justice on deviant workplace behavior. The direct influence of interpersonal justice on deviant workplace behavior is significant, so the indirect influence of interpersonal justice on deviant workplace behavior through job satisfaction is significant. (Alias, Rasdi, Ismail, \& Samah, 2013) said, employees with negative feelings, get injustice will get dissatisfaction and will be more likely to be involved in various things deviant behavior. So from that it can be stated that job satisfaction can mediate the relationship between interpersonal justice and deviant workplace behavior.

Job Satisfaction Mediates Non-Physical Work Environment to Deviant Workplace Behavior

The direct effect of the non-physical work environment on deviant workplace behavior is not significant, but the effect of the non-physical work environment on job satisfaction is significant and the effect of job satisfaction on deviant workplace behavior is significant. In accordance with the rules of Baron and Kenney in (Jogiyanto, 2011) that testing of mediation effects can be done if the main effect (direct relationship of the exogent variable to the endogent) is significant. If this does not occur, the mediation effect test cannot continue. The results of the study are not inconsistent with previous research conducted by Chandler in (Alias et al., 2013) the unfavorable non-physical work environment will contribute to dissatisfaction and then will increase deviant workplace behavior.

\section{Conclusions}

The results of analysis and discussion on the effect of interpersonal justice and non-physical work environment on deviant workplace behavior with job satisfaction as a mediating variable in Universitas Negeri Padang employees, it can be concluded that Interpersonal Justice and NonPhysical Work Environment have a positive and significant effect on job satisfaction, then Job Satisfaction, and Interpersonal Justice have negative significant effect on Deviant Workplace Behavior. However, the Non-Physical Work Environment variable does not have a significant effect on the Deviant Workplace Behavior variable.

In accordance with research, interpersonal justice more influence the occurrence on deviant workplace behavior. Supervisor must treat employees with respect and must be able to maintain their expression. Because in accordance with the results of the study, interpersonal justice affects on deviant workplace behavior negatively and significantly. If organization want the deviant workplace behavior to be reduced, job satisfaction must also be considered and improved again. Supervisor should give assignments to employees according to their skills, the promotion process must be open, employers must have a pleasant attitude, and fellow colleagues must support each other, and the intensity of cooperation between employees must be well established. The higher job satisfaction obtained employees, the deviant workplace behavior will decrease.

\section{References}

Judge, T. A., Scott, B. A., \& Ilies, R. (2006). Hostility, job attitudes, and workplace deviance: Test of a multilevel model. Journal of Applied Psychology, 91(1), 126-138. https://doi.org/10.1037/00219010.91.1.126 
Berry, C. M., Ones, D. S., \& Sackett, P. R. (2007). Interpersonal deviance, organizational deviance, and their common correlates: A review and meta-analysis. Journal of Applied Psychology, 92(2), 410424. https://doi.org/10.1037/0021-9010.92.2.410

Kafui Agbozo, G. (2017). The Effect of Work Environment on Job Satisfaction: Evidence from the Banking Sector in Ghana. Journal of Human Resource Management, 5(1), 12. https://doi.org/10.11648/j.jhrm.20170501.12

Alias, M., Rasdi, R. M., Ismail, M., \& Samah, B. A. (2013). Predictors of workplace deviant behaviour: HRD agenda for Malaysian support personnel. European Journal of Training and Development, 37(2), 161-182. https://doi.org/10.1108/03090591311301671

Robinson, S. L., Bennett, R. J., Academy, T., Apr, N., Robinson, S. L., \& Bennett, R. J. (2008). A Typology of Deviant Workplace Behaviors: A Multidimensional Scaling Study A TYPOLOGY OF DEVIANT WORKPLACE BEHAVIORS : A MULTIDIMENSIONAL SCALING STUDY. 38(2), 555-572.

Faheem, M. A., \& Mahmud, N. (2015). The Effects of Organizational Justice on Workplace Deviance and Job Satisfaction of Employees: Evidence from a Public Sector Hospital of Pakistan. Mediterranean Journal of Social Sciences, 6(5), 342-352. https://doi.org/10.5901/mjss.2015.v6n5p342

Griffin, R. W., \& Lopez, Y. P. (2005). "Bad behavior" in organizations: A review and typology for future research. Journal of Management, 31(6), 988-1005. https://doi.org/10.1177/0149206305279942

Cahyani, Ika Damayanti Nur. 2016. Penyebab dan Akibat Perilaku Menyimpang di Tempat Kerja. Jurnal Ekonomi \& Bisnis. 10(3), 175-189.

Henle, C. A. (2005), Predicting workplace deviance from the interaction between organizational justice and personality. Journal of Managerial Issues. 17(2), 247-63.

Jogiyanto. 2011. Konsep dan Aplikasi Structural Equation Modeling Berbasis Varian dalam Penelitian Bisnis . Yogyakarta: STIM YKPN.

Omar, F., Halim, F. W., Ahmad Zamani, Z., Farhadi, H., Nasir, R., \& Khairudin, R. (2011). Stress and job satisfaction as antecedents of workplace deviant behavior. World Applied Sciences Journal, 12(SPL ISS.), 46-51. 